\title{
Development of Hesitant Fuzzy-Based Project Selection Method with Consideration of Benefits, Opportunities, Costs and Risks
}

\author{
Karina Ayu Trijana and Udisubakti Ciptomulyono \\ Department of Technology Management, Institut Teknologi Sepuluh Nopember, Surabaya \\ e-mail:ikrnts@gmail.com
}

\begin{abstract}
PT X, a power generation company, hasn't been able to meet their target in the business development segment over the past few years. This is due to a problem detected in their Project Portfolio Management, in which PT X's project selection method hasn't considered the ambiguity nature of project's information and risks. This study is going to develop a project selection method for PT X using MCDM (multi criteria decision making) with BOCR (benefit, opportunity, cost, risk) Concept to evaluate many criteria that need to be considered by the company, especially conflicting criteria such as benefit with cost and opportunity with risk. Not only that, hesitant fuzzy will be used because project itself has many uncertain or ambiguous information, so stakeholder will face difficulties in determining the value for the evaluation. From the integration of those things in this study, it is found that for PT X, Benefit has the biggest priority, followed by Opportunity, Risk, and Cost in Project Selection for PT $X$. It is also found that based on additiveBOCR, Project $C$ gives the optimal value for PT $X$, followed by Project B, Project A, Project D, dan Project E.
\end{abstract}

Keywords-BOCR, Hesitant Fuzzy, MCDM, Project Selection, Project Portfolio Management.

\section{INTRODUCTION}

$\mathrm{C}$ URRENTLY, a massive electricity infrastructure development is being carried out by the Government of Indonesia, which was launched under the name of the 35,000 MW Program [1].This program is listed in the Electricity Supply Business Plan (RUPTL) of PT PLN (Persero), which is annually approved by a Decree of the Minister of Energy and Mineral Resources. In the 2019-2028 RUPTL, which is the last RUPTL which was ratified on 20 February 2019, it is planned that there will be an increase in generating capacity in Indonesia by 56,395 MW. This plan is projected to cause Indonesia to have a power plant capacity of $97,072 \mathrm{MW}$ by the end of 2028.

It can be seen that many new power plants will emerge in Indonesia. This indicates that competition among power plants in Indonesia will increase significantly. One company that was affected by this change is PT X, a company engaged in the field of electricity generation in Indonesia. To face this issue, PT X tried to seize this huge opportunity by participating in the 35,000 MW Program. However, PT X has never achieved the target set by them for the past few years. That is because the company's project selection method has not consider the ambiguity or uncertainty of project information, as well as the risks of the project.

\section{A. Project Selection Method}

In doing business development and increasing its competitive advantage, a company can carry out a set of projects. A group of projects and / or programs and other work that are grouped together to facilitate effective management so that the work can meet the company's strategic objectives is called a portfolio [2]. Project Portfolio Management itself is the management of a portfolio with the aim to maximize the project's contribution to the health and success of the company [3]. One of the steps in this management is the alignment of the project portfolio with the company's strategy, which consists of identification of project until the project authorization [2].

Implementation of project portfolio management can use a variety of techniques to ensure that project investment directly contributes to the achievement of company goals [4]. Some popular methods used by decision makers in portfolio selection activities are AHP, valuation models, and portfolio matrices because these methods can help users in considering the qualitative and quantitative characteristics of the project [5]. The application of one method, namely the scoring model, where the project is assessed based on several criteria as the basis of prioritization or project selection, was found to produce the portfolio with the highest benefits when compared to other methods [6].

\section{B. Multi Criteria Decision Making dalam Pemilihan Proyek}

MCDM is a concept, approach, model, and method to assist decision makers in describing, evaluating, sorting, ranking, choosing or rejecting a thing (candidates, products, projects, etc.) based on evaluation (which can be in the form of scores, scores, preference) for several criteria [7]. In project selection, of course, each project has different advantages and disadvantages. Due to the many different and conflicting criteria that need to be considered in project selection, MCDM is indeed an appropriate method to be used.

Even so, MCDM as a method of project selection has limitations. MCDM will provide the most optimal results when the scores and importance of the criteria are known with certainty [8]. However, in practice, decision making is carried out in an environment where the aims, boundaries, and consequences are not known with certainty. To overcome this, the use of fuzzy was introduced in MCDM [9].

There are many types of fuzzy that have now been applied in MCDM to integrate ambiguity or uncertainty of a decision. One of the uncertainty problems faced is the existence of 
Table 1.

Fuzzy Scale for AHP/ANP based on Saaty's Scale [28]

\begin{tabular}{ccc}
\hline \hline Rate & Definition & TFN $(\boldsymbol{\theta}=\mathbf{1})$ \\
\hline 1 & Equal & $(1,1,1)$ \\
3 & Slightly more important & $(2,3,4)$ \\
5 & Significantly more important & $(4,5,6)$ \\
7 & Very significantly more important & $(6,7,8)$ \\
9 & Absolutely more important & $(8,9,10)$ \\
$(2,4,6,8)$ & In between & $((\mathrm{x}-\theta), \mathrm{x},(\mathrm{x}+\theta))$ \\
$1 / \mathrm{x}$ & Reciprocal & $(1 /(\mathrm{x}+\theta), 1 / \mathrm{x}, 1 /(\mathrm{x}-\theta))$ \\
\hline \hline
\end{tabular}

Table 2.

Fuzzy Scale for DEMATEL [29]

\begin{tabular}{ccc}
\hline \hline Rate & Definition & TFN \\
\hline 0 & No influence & $(0,0,0.25)$ \\
1 & Very low influence & $(0,0.25,0.25)$ \\
2 & Low influence & $(0.25,0.5,075)$ \\
3 & High influence & $(0.5,0.75,1)$ \\
4 & Very high influence & $(0.75,1,1)$ \\
\hline \hline
\end{tabular}

Table 3.

Criteria and Sub-Criteria for BOCR Network

\begin{tabular}{ll}
\hline \hline \multicolumn{1}{c}{ Benefit } & Cost \\
\hline Economical & Economical \\
Tariff & Investment Cost \\
Economic Value & Primary Energy Cost \\
Influence to Company's Cashflow & O\&M Cost \\
Technical & Technical \\
Feasibility & Distance Between Primary Energy and User \\
Efficiency & Project Phase Duration \\
& Distance Between Power Plant and Transmission \\
\hline \multicolumn{1}{c|}{ Opportunity } & \\
\hline Technical Risk \\
Opportunity for EBT Development & Legal \\
Opportunity for Dispatch & Legal Risk \\
Primary Energy Availability & Technical \\
Contract Provisions & Contractual Risk \\
Economical & Construction Risk \\
Contribution to Economy & Company's Management \\
Fund Availability & Strategic Risk \\
Social and Political & Failure Risk \\
Government's Support & \\
\hline \hline
\end{tabular}

Table 4.

Hesitant Evalution for Decision Maker 1

\begin{tabular}{cccc}
\hline \hline Strategic Criteria & Solution \& Value Added & $\begin{array}{c}\text { High quality, competitive, and } \\
\text { environmental friendly }\end{array}$ & Sustainable \\
\hline $\begin{array}{c}\text { Solution \& Value Added } \\
\text { High quality, competitive, and } \\
\text { environmental friendly } \\
\text { Sustainable }\end{array}$ & EE & $(1 / 5,1 / 3)$ & $(1 / 7,1 / 5)$ \\
$(1 / 3,1)$ & EE & EE \\
\hline \hline
\end{tabular}

several values or events that may occur, so that decision makers experience doubts in giving their decisions. Fuzzy types such as Type-1 [10] or Type-2 [11] certainly cannot be used to describe this event, because decision makers must still determine one value for their decisions. Therefore, Torra [12] proposes a fuzzy hesitant in which this function will describe the doubts of decision makers in their evaluations.

In making decisions, it is also important to note that the results received by a company are not only positive, but also negative. Benefits and opportunities are the positive effects of a decision, while the costs and risks are the negative impacts. To be able to evaluate decisions carefully by considering these four aspects, Saaty [13] proposes the concept of BOCR (benefit, opportunity, cost, and risk). This method is a concept that illustrates the decision making environment into four networks, namely: benefits, opportunities, costs, and risks. This concept can help decision makers evaluate the positive and negative impacts of an alternative simultaneously [14]. In each aspect, alternatives will be evaluated, wherein then the four assessments will be combined into one result that illustrates the value of an alternative.

To choose crucial things such as projects to be carried out by a company, it would be better if the method used can provide accurate results and in accordance with company objectives, taking into account the uncertainty of information and the impact given by the project. There has been many paper proposing the implementation of MCDM, such as AHP or ANP, integrated with other concepts, such as fuzzy or BOCR, for project selection [15-20]. Therefore, in this study, another integration method will be developed using the hesitant fuzzy concept and the BOCR Concept in project selection. 
Table 5 .

Fuzzy Envelopes Evaluation for Decision Maker 1

\begin{tabular}{|c|c|c|c|c|c|c|c|c|c|c|c|c|}
\hline \multirow{2}{*}{ Strategic Criteria } & \multicolumn{4}{|c|}{ Solution \& Value Added } & \multicolumn{4}{|c|}{$\begin{array}{l}\text { High quality, competitive, and } \\
\text { environmental friendly }\end{array}$} & \multicolumn{4}{|c|}{ Sustainable } \\
\hline & $\mathbf{L}$ & M1 & M2 & $\mathbf{H}$ & $\mathbf{L}$ & M1 & M2 & $\mathbf{H}$ & $\mathbf{L}$ & M1 & M2 & $\mathbf{H}$ \\
\hline $\begin{array}{l}\text { Solution \& Value } \\
\text { Added }\end{array}$ & 1.000 & 1.000 & 1.000 & 1.000 & 0.167 & 0.243 & 0.257 & 0.500 & 0.125 & 0.163 & 0.170 & 0.250 \\
\hline $\begin{array}{l}\text { High quality, } \\
\text { competitive, and } \\
\text { environmental } \\
\text { friendly }\end{array}$ & & & & & 1.000 & 1.000 & 1.000 & 1.000 & 0.250 & 0.476 & 0.524 & 1.000 \\
\hline Sustainable & & & & & & & & & 1.000 & 1.000 & 1.000 & 1.000 \\
\hline
\end{tabular}

Table 6.

Aggregate Matrices of Strategic Criteria from All Decision Makers

\begin{tabular}{|c|c|c|c|c|c|c|c|c|c|c|c|c|}
\hline \multirow[t]{2}{*}{ Strategic Criteria } & \multicolumn{4}{|c|}{ Solution \& Value Added } & \multicolumn{4}{|c|}{$\begin{array}{c}\text { High quality, competitive, and } \\
\text { environmental friendly }\end{array}$} & \multicolumn{4}{|c|}{ Sustainable } \\
\hline & $\mathbf{L}$ & M1 & M2 & $\mathbf{H}$ & $\mathbf{L}$ & M1 & M2 & $\mathbf{H}$ & $\mathbf{L}$ & M1 & M2 & $\mathbf{H}$ \\
\hline $\begin{array}{c}\text { Solution \& Value } \\
\text { Added }\end{array}$ & 1.000 & 1.000 & 1.000 & 1.000 & 0.220 & 0.263 & 0.274 & 0.359 & 0.304 & 0.390 & 0.394 & 0.574 \\
\hline $\begin{array}{l}\text { High quality, } \\
\text { competitive, and } \\
\text { environmental } \\
\text { friendly }\end{array}$ & 2.787 & 3.656 & 3.798 & 4.547 & 1.000 & 1.000 & 1.000 & 1.000 & 1.213 & 1.548 & 1.620 & 2.096 \\
\hline Sustainable & 1.741 & 2.541 & 2.561 & 3.288 & 0.477 & 0.617 & 0.646 & 0.824 & 1.000 & 1.000 & 1.000 & 1.000 \\
\hline
\end{tabular}

Table 7.

Weights for Strategic Criteria

\begin{tabular}{|c|c|c|c|c|c|}
\hline \multirow{2}{*}{ Strategic Criteria } & \multicolumn{4}{|c|}{ "Fuzzy Weight } & \multirow{2}{*}{ Crisp Weight } \\
\hline & $\mathbf{L}$ & M1 & M2 & $\mathbf{H}$ & \\
\hline $\begin{array}{c}\text { Solution \& Value } \\
\text { Added }\end{array}$ & 0.041 & 0.047 & 0.048 & 0.059 & $13.898 \%$ \\
\hline $\begin{array}{l}\text { High quality, } \\
\text { competitive, and } \\
\text { environmental } \\
\text { friendly }\end{array}$ & 0.150 & 0.178 & 0.183 & 0.212 & $52.270 \%$ \\
\hline Sustainable & 0.094 & 0.116 & 0.118 & 0.139 & $33.833 \%$ \\
\hline
\end{tabular}

Table 8 .

Weights for BOCR

\begin{tabular}{|c|c|c|c|c|c|c|c|c|c|c|c|c|c|c|c|c|c|}
\hline \multirow{4}{*}{$\begin{array}{l}\text { Meri } \\
\text { ts }\end{array}$} & \multicolumn{4}{|c|}{ Solution \& Value Added } & \multicolumn{5}{|c|}{$\begin{array}{l}\text { High quality, competitive, } \\
\text { and environmental friendly }\end{array}$} & \multicolumn{4}{|c|}{ Sustainable } & \multicolumn{3}{|c|}{ Fuzzy Weight } & \multirow[t]{2}{*}{$\begin{array}{r}\text { Crisp } \\
\text { Weigh }\end{array}$} \\
\hline & $\mathbf{L}$ & M1 & M2 & $\mathbf{H}$ & $\mathbf{L}$ & M1 & M2 & $\mathbf{H}$ & $\mathbf{L}$ & M1 & M2 & $\mathbf{H}$ & & & & & \\
\hline & 0.04 & 0.04 & 0.04 & 0.05 & 0.15 & 0.17 & 0.18 & 0.21 & 0.09 & 0.11 & 0.11 & 0.13 & $\mathbf{L}$ & M1 & M2 & $\mathbf{H}$ & \\
\hline & 1 & 7 & 8 & 9 & $\mathbf{0}$ & 8 & 3 & 2 & 4 & 6 & 8 & 9 & & & & & \\
\hline \multirow{2}{*}{ B } & 0.13 & 0.16 & 0.16 & 0.19 & 0.11 & 0.14 & 0.14 & 0.17 & 0.08 & 0.11 & 0.10 & 0.13 & 0.0 & 0.04 & 0.04 & 0.06 & 33.127 \\
\hline & 1 & 2 & 6 & 6 & 3 & 8 & 7 & 4 & 5 & 0 & 8 & 7 & 30 & 7 & 8 & 8 & $\%$ \\
\hline \multirow{2}{*}{$\mathrm{O}$} & 0.08 & 0.09 & 0.10 & 0.12 & 0.08 & 0.10 & 0.10 & 0.12 & 0.07 & 0.09 & 0.09 & 0.11 & 0.0 & 0.03 & 0.03 & 0.04 & 23.930 \\
\hline & 0 & 8 & 1 & 6 & 8 & 0 & 0 & 0 & 3 & 2 & 2 & 9 & 23 & 3 & 4 & 9 & $\%$ \\
\hline \multirow{2}{*}{$\mathrm{C}$} & 0.06 & 0.07 & 0.07 & 0.08 & 0.07 & 0.08 & 0.08 & 0.10 & 0.07 & 0.09 & 0.09 & 0.11 & 0.0 & 0.02 & 0.03 & 0.04 & 20.889 \\
\hline & 2 & 2 & 4 & 8 & 5 & 5 & 5 & 2 & 3 & 1 & 1 & 0 & 21 & 9 & 0 & 2 & $\%$ \\
\hline \multirow{2}{*}{$\mathrm{R}$} & 0.07 & 0.08 & 0.08 & 0.09 & 0.06 & 0.07 & 0.08 & 0.09 & 0.09 & 0.10 & 0.11 & 0.13 & 0.0 & 0.03 & 0.03 & 0.04 & 22.054 \\
\hline & 3 & 3 & 4 & 9 & 8 & 9 & 0 & 4 & 1 & 9 & 1 & 4 & 22 & 1 & 2 & 4 & $\%$ \\
\hline
\end{tabular}

\section{METHODOLOGY}

\section{A. BOCR Concept}

Every decision not only has a positive impact, but also a negative which needs to be considered by decision makers [21]. Benefits and opportunities are the positive effects of a decision, while the costs and risks are the negative impacts. The benefit itself is a positive impact that is certain to be obtained by a company, while the cost is a negative impact that must be received. Positive impacts that are uncertain are opportunities, while negative impacts that are uncertain are risks [13]. These four aspects can reduce or increase the value of a choice.

To be able to evaluate decisions carefully by considering these four aspects, Saaty [13] proposes the concept of BOCR (benefit, opportunity, cost, and risk). This method is a concept that describes the decision making environment into four networks, namely: benefits, opportunities, costs, and risks. In each aspect, alternatives will be evaluated, wherein then the four assessments will be combined into one result that illustrates the value of an alternative. Benefits, opportunities, costs and risks must also be prioritized based on strategic criteria [13]. Then, the evaluation results from each aspect 
Table 9.

Dispatcher and Receiver Value for Each Sub-Criteria

\begin{tabular}{|c|c|c|c|c|c|c|c|c|c|}
\hline Benefit & $\overline{D D}$ & $\overline{\mathbf{R}}$ & D-R & $\overline{D D+R}$ & Cost & D & $\overline{\mathbf{R}}$ & D-R & $\overline{\mathbf{D}+\mathbf{R}}$ \\
\hline Economical & & & & & Economical & & & & \\
\hline Tariff & 9.048 & 9.209 & 18.257 & -0.161 & Investment Cost & 3.501 & 3.906 & 7.407 & -0.405 \\
\hline Economic Value & 8.652 & 9.383 & 18.035 & -0.731 & $\begin{array}{l}\text { Primary Energy } \\
\text { Cost }\end{array}$ & 3.333 & 3.297 & 6.629 & 0.036 \\
\hline $\begin{array}{l}\text { Influence to } \\
\text { Company's } \\
\text { Cashflow }\end{array}$ & 8.659 & 8.789 & 17.448 & -0.130 & O\&M Cost & 2.945 & 3.231 & 6.176 & -0.286 \\
\hline Technical & & & & & $\begin{array}{l}\text { Technical } \\
\text { Distance }\end{array}$ & & & & \\
\hline Feasibility & 9.172 & 9.147 & 18.319 & 0.025 & $\begin{array}{l}\text { Between Primary } \\
\text { Energy and User }\end{array}$ & 3.509 & 3.237 & 6.746 & 0.272 \\
\hline \multirow[t]{2}{*}{ Efficiency } & 9.049 & 8.051 & 17.099 & 0.998 & $\begin{array}{l}\text { Project Phase } \\
\text { Duration }\end{array}$ & 3.286 & 3.537 & 6.824 & -0.251 \\
\hline & & & & & $\begin{array}{l}\text { Distance } \\
\text { Between Power } \\
\text { Plant and } \\
\text { Transmission }\end{array}$ & 3.663 & 3.029 & 6.692 & 0.633 \\
\hline Opportunity & D & $\mathbf{R}$ & D-R & $\mathbf{D}+\mathbf{R}$ & Risk & D & $\mathbf{R}$ & D-R & $\mathbf{D}+\mathbf{R}$ \\
\hline Technical & & & & & Legal & & & & \\
\hline $\begin{array}{l}\text { Opportunity for } \\
\text { EBT } \\
\text { Development }\end{array}$ & 4.057 & 4.359 & 8.416 & -0.302 & Legal Risk & 9.109 & 9.203 & 18.311 & -0.094 \\
\hline $\begin{array}{l}\text { Opportunity for } \\
\text { Dispatch } \\
\text { Primary Energy }\end{array}$ & 4.017 & 3.898 & 7.915 & 0.119 & Technical & & & & \\
\hline $\begin{array}{l}\text { Sources } \\
\text { Availability }\end{array}$ & 4.133 & 3.807 & 7.941 & 0.326 & Contractual Risk & 9.050 & 8.942 & 17.991 & 0.108 \\
\hline $\begin{array}{l}\text { Contract } \\
\text { Provisions }\end{array}$ & 3.917 & 3.926 & 7.843 & -0.009 & $\begin{array}{l}\text { Construction } \\
\text { Risk }\end{array}$ & 9.149 & 9.065 & 18.215 & 0.084 \\
\hline Economical & & & & & Company's Man & nent & & & \\
\hline $\begin{array}{l}\text { Contribution to } \\
\text { Economy }\end{array}$ & 3.714 & 3.797 & 7.511 & -0.083 & Strategic Risk & 8.715 & 8.907 & 17.622 & -0.192 \\
\hline Fund Availability & 3.865 & 3.907 & 7.771 & -0.042 & Failure Risk & 9.096 & 9.002 & 18.097 & 0.094 \\
\hline $\begin{array}{l}\text { Social and Politic } \\
\text { Government's } \\
\text { Support }\end{array}$ & 3.952 & 3.961 & 7.913 & -0.009 & & & & & \\
\hline
\end{tabular}

Table 10 .

Weighted Supermatrix for Benefit Network

\begin{tabular}{|c|c|c|c|c|c|c|c|}
\hline Cluster & Node & Best Benefit & $\begin{array}{c}\text { Economic } \\
\text { Value }\end{array}$ & $\begin{array}{c}\text { Influence to } \\
\text { Company's } \\
\text { Cashflow } \\
\end{array}$ & Tariff & Efficiency & Feasibility \\
\hline \multirow[t]{2}{*}{ Goal } & Best Benefit & 0.000 & 0.000 & 0.000 & 0.000 & 0.000 & 0.000 \\
\hline & $\begin{array}{l}\text { Economy } \\
\text { Value }\end{array}$ & 0.502 & 0.000 & 0.614 & 0.487 & 0.215 & 0.474 \\
\hline \multirow[t]{2}{*}{ Economical } & $\begin{array}{l}\text { Influence to } \\
\text { Company's } \\
\text { Cashflow }\end{array}$ & 0.159 & 0.000 & 0.000 & 0.351 & 0.092 & 0.334 \\
\hline & Tariff & 0.170 & 0.838 & 0.224 & 0.000 & 0.108 & 0.192 \\
\hline \multirow{2}{*}{ Technical } & Efficiency & 0.059 & 0.000 & 0.000 & 0.000 & 0.000 & 0.000 \\
\hline & Feasibility & 0.110 & 0.162 & 0.162 & 0.162 & 0.586 & 0.000 \\
\hline
\end{tabular}

Table 11.

Limiting Supermatrix for Benefit Network

\begin{tabular}{|c|c|c|c|c|c|c|c|}
\hline Cluster & Node & Best Benefit & $\begin{array}{c}\text { Economic } \\
\text { Value }\end{array}$ & $\begin{array}{c}\text { Influence to } \\
\text { Company's } \\
\text { Cashflow }\end{array}$ & Tariff & Efficiency & Feasibility \\
\hline \multirow[t]{2}{*}{ Goal } & Best Benefit & 0.000 & 0.000 & 0.000 & 0.000 & 0.000 & 0.000 \\
\hline & $\begin{array}{l}\text { Economy } \\
\text { Value }\end{array}$ & 0.341 & 0.341 & 0.341 & 0.341 & 0.341 & 0.341 \\
\hline \multirow[t]{2}{*}{ Economical } & $\begin{array}{c}\text { Influence to } \\
\text { Company's } \\
\text { Cashflow }\end{array}$ & 0.169 & 0.169 & 0.169 & 0.169 & 0.169 & 0.169 \\
\hline & Tariff & 0.350 & 0.350 & 0.350 & 0.350 & 0.350 & 0.350 \\
\hline \multirow{2}{*}{ Technical } & Efficiency & 0.000 & 0.000 & 0.000 & 0.000 & 0.000 & 0.000 \\
\hline & Feasibility & 0.139 & 0.139 & 0.139 & 0.139 & 0.139 & 0.139 \\
\hline
\end{tabular}

can be synthesized and combined into one value using several formulas. The following are some formulas that can be used [13]: (i) multiplicative which is a marginal formula (1) and (ii) additive that describes the final result in total or global (2). 
Table 12.

Weights for BOCR Network

\begin{tabular}{|c|c|c|c|c|c|}
\hline Benefit & Local Weight & Global Weight & Cost & Local Weight & Global Weight \\
\hline Economical & & & Economical & & \\
\hline Tariff & $40.709 \%$ & $35.038 \%$ & Investment Cost & $52.827 \%$ & $42.691 \%$ \\
\hline Economic Value & $39.602 \%$ & $34.085 \%$ & Primary Energy Cost & $37.325 \%$ & $30.163 \%$ \\
\hline $\begin{array}{l}\text { Influence to Company's } \\
\text { Cashflow }\end{array}$ & $19.689 \%$ & $16.946 \%$ & O\&M Cost & $9.848 \%$ & $7.958 \%$ \\
\hline Technical & & & $\begin{array}{l}\text { Technical } \\
\text { Distance Between }\end{array}$ & & \\
\hline Feasibility & $100.000 \%$ & $13.932 \%$ & $\begin{array}{l}\text { Primary Energy and } \\
\text { User }\end{array}$ & $48.378 \%$ & $9.282 \%$ \\
\hline \multirow[t]{2}{*}{ Efficiency } & $0.000 \%$ & $0.000 \%$ & $\begin{array}{l}\text { Project Phase Duration } \\
\text { Distance Between }\end{array}$ & $51.622 \%$ & $9.905 \%$ \\
\hline & & & $\begin{array}{l}\text { Power Plant and } \\
\text { Transmission }\end{array}$ & $0.000 \%$ & $0.000 \%$ \\
\hline Opportunity & Local Weight & Global Weight & Risk & Local Weight & Global Weight \\
\hline Technical & & & Legal & & \\
\hline $\begin{array}{l}\text { Opportunity for EBT } \\
\text { Development }\end{array}$ & $38.993 \%$ & $24.318 \%$ & Legal Risk & $100.000 \%$ & $32.144 \%$ \\
\hline Opportunity for Dispatch & $24.703 \%$ & $15.406 \%$ & Technical & & \\
\hline $\begin{array}{l}\text { Primary Energy Sources } \\
\text { Availability }\end{array}$ & $21.537 \%$ & $13.431 \%$ & Contractual Risk & $41.899 \%$ & $11.162 \%$ \\
\hline $\begin{array}{l}\text { Contract Provisions } \\
\text { Economical }\end{array}$ & $14.766 \%$ & $9.209 \%$ & $\begin{array}{l}\text { Construction Risk } \\
\text { Company's Management }\end{array}$ & $58.101 \%$ & $15.477 \%$ \\
\hline Contribution to Economy & $39.132 \%$ & $9.842 \%$ & Strategic Risk & $38.506 \%$ & $15.871 \%$ \\
\hline Fund Availability & $60.868 \%$ & $15.309 \%$ & Failure Risk & $61.494 \%$ & $25.346 \%$ \\
\hline \multicolumn{6}{|l|}{ Social and Political } \\
\hline Government's Support & $12.485 \%$ & $12.485 \%$ & & & \\
\hline
\end{tabular}

Table 13.

Synthesis BOCR Value for Projects

\begin{tabular}{ccccccc}
\hline \hline \multirow{2}{*}{ Project } & Benefit & Opportunity & Cost & Risk & Synthesis \\
\cline { 2 - 6 } & $\mathbf{3 3 . 1 2 7 \%}$ & $\mathbf{2 3 . 9 3 0 \%}$ & $\mathbf{2 0 . 8 8 9 \%}$ & $\mathbf{2 2 . 0 5 4 \%}$ & Additive & Multiplicative \\
\hline Project A & 0.204 & 0.194 & 0.196 & 0.211 & 0.026 \\
Project B & 0.215 & 0.191 & 0.199 & 0.198 & 0.032 \\
Project C & 0.217 & 0.248 & 0.226 & 0.202 & 0.039 \\
Project D & 0.191 & 0.191 & 0.193 & 0.208 & 0.023 \\
Project E & 0.173 & 0.176 & 0.186 & 0.181 & 0.021 \\
\hline \hline
\end{tabular}

Table 14.

Project Selection and Prioritization Based on Synthesis BOCR

\begin{tabular}{ccc}
\hline \hline Project & Rank & Decision \\
\hline Project C & 1 & Selected \\
Project B & 2 & Selected \\
Project A & 3 & Selected with Mitigation Plan \\
Project D & 4 & Selected with Mitigation Plan \\
Project E & 5 & Selected with Mitigation Plan \\
\hline \hline
\end{tabular}

$$
B_{i} O_{i} / C_{i} R_{i}
$$

$$
{ }^{b} B_{i}+o O_{i}-c C_{i}-r R_{i}
$$

\section{B. Analytic Hierarchy Process and Analytic Network} Process

AHP was introduced by Saaty [22], which is a complex decision analysis method that qualitatively compares each criteria in pairs. In AHP, the analysis process is carried out in two phases, namely (i) structuring the problem, (ii) determining priorities based on pairwise comparisons [23]. Then, a comparison is made between each variable to get priority weighting. Lower level priorities will follow from upper level priorities.

Saaty [22] states that AHP does not pay attention to the relationship and interaction between criteria that can affect the performance of these criteria. This is a weakness of AHP, where many decision problems cannot be arranged based on a hierarchical structure due to interactions and dependencies between elements at the top level and elements at the bottom level. Analytical Network Process (ANP) emerged as a method developed from AHP, where problems have a network structure (network) and comparisons are made by taking into account the relationship between these criteria.

According to Saaty [24], hierarchy is a structure that is straight from top to bottom, while the network is a structure that is spread in various directions and includes cycles between clusters and within the same cluster. Decisions made based on network structure will produce different results from decisions based on hierarchical structure.

\section{DEMATEL}

DEMATEL is used to estimate the direct and indirect causal relations between several factors developed by Fontela and Gabus [25]. This method is a comprehensive technique in compiling and analyzing cause-effect relationships between factors. The final result of DEMATEL is a map that represents the relationship between factors or impact-relation map (IRM). 


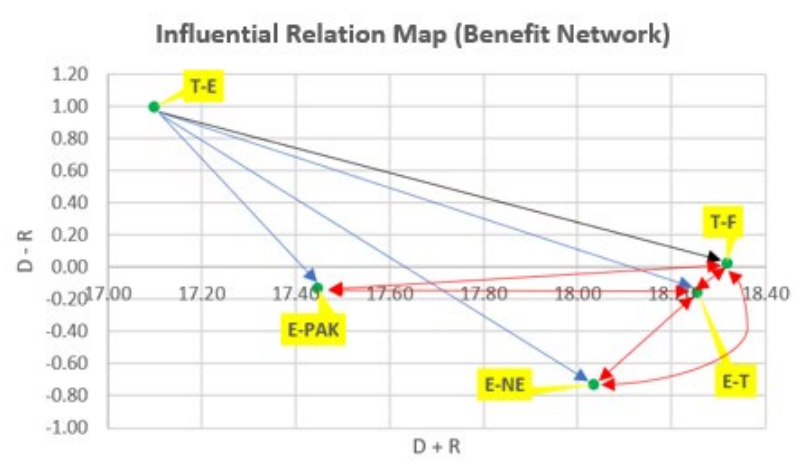

(a)

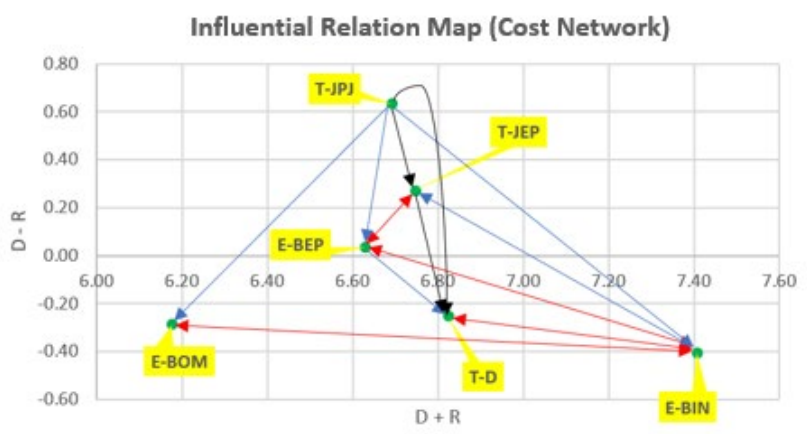

(c)

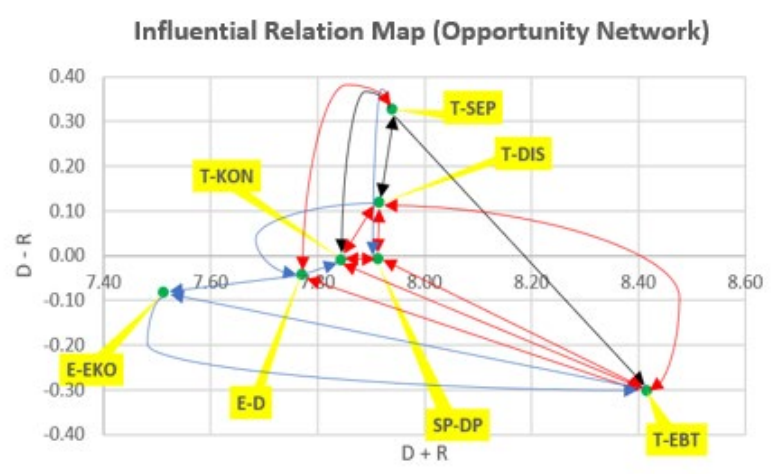

(b)

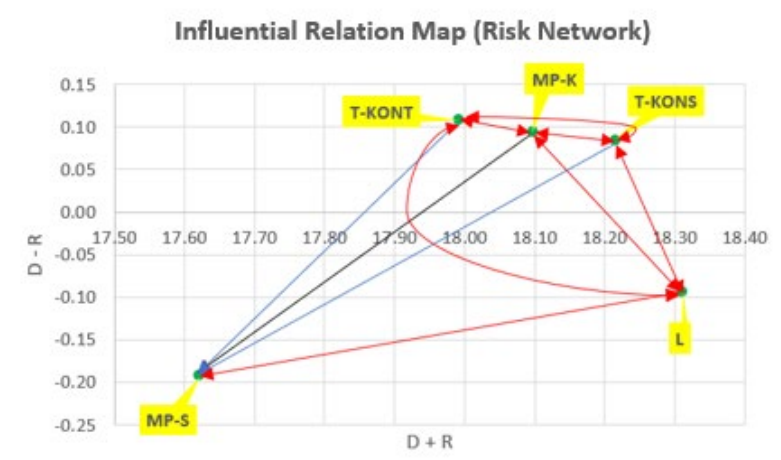

(d)

\section{$\rightarrow \quad$ Innerdependence $\rightarrow \quad$ Quterdependence $\leftrightarrow \quad$ Bidirectional}

Figure 1. Influential Relation Map for BOCR Network: (a) Benefit, (b) Opportunity, (c) Cost, (d) Risk.

\section{Fuzzy}

The use of fuzzy in MCDM is implemented when the achievement of objectives cannot be defined with crisp or definite data [26]. Fuzzy integration in MCDM has led to the emergence of methods that can solve problems that previously could not be solved by conventional MCDM [8].

There are four types of fuzzy that have been widely applied in MCDM: (a) Type-1 Fuzzy [10], which is the simplest fuzzy function, (b) Type-2 Fuzzy [11], which is a function developed from Type-1 Fuzzy, where the function can describe uncertainties related to the membership function, (c) Intuitionistic Fuzzy [27], which describes consideration of possible errors (errors) of the decision-making judgment, and (d) Hesitant Fuzzy [12], which describes the function in which decision makers experience doubts regarding their preferences in valuation.

\section{PROPOSED MODEL}

The proposed model for a company to select projects to become their portfolio is composed of the following steps:

1. Identify the decision makers.

2. Identify the strategic criteria and control hierarchy.

3. Identify the criteria and sub-criteria for BOCR networks.

4. Identify the weights of strategic criteria and weights of BOCR based on strategic criteria using hesitant fuzzy AHP [30]. The scale in Table 1 is used for this calculation.

5. Identify the significant dependencies among criteria and sub-criteria in the BOCR networks using fuzzy DEMATEL [31]. The scale in Table 2 is used for this calculation.
6. Identify the weights of BOCR criteria and sub-criteria using hesitant fuzzy ANP. SuperDecision software and scale in Table 1 are used for this calculation.

7. Evaluate and select power plant projects using additiveBOCR and multiplicative-BOCR. The ranked will be determined based on additive-BOCR, ranked from the highest value (the most prioritized project) to the lowest value (the least prioritized project).

\section{CASE STUDY}

This proposed model will be implemented in PT X, an electricity company based on Indonesia, to select from five projects based on RUPTL 2019-2028. Below are the explanations.

Step 1. Identify the decision makers: For this paper, five decision makers are chosen who are head of divisions and experts in power plant development of PT X. The decision makers then will be questioned using questionnaires to identify criteria, their dependencies with each other, and their weight based on their importance.

Step 2. Identify the strategic criteria and control hierarchy: Based on interview with decision makers, it is decided that PT X's missions will be the strategic criteria for the project selections. This is because when making a decision, especially investment decisions such as the implementation of a project, it is necessary to ensure that the project is aligned with the company's goals, as outlined in the vision. Missions, as derivatives and steps to achieve vision, is suitable as a strategic criterion. Mission as a strategic criterion can ensure that the results of this method are in line with the company's 
(a)
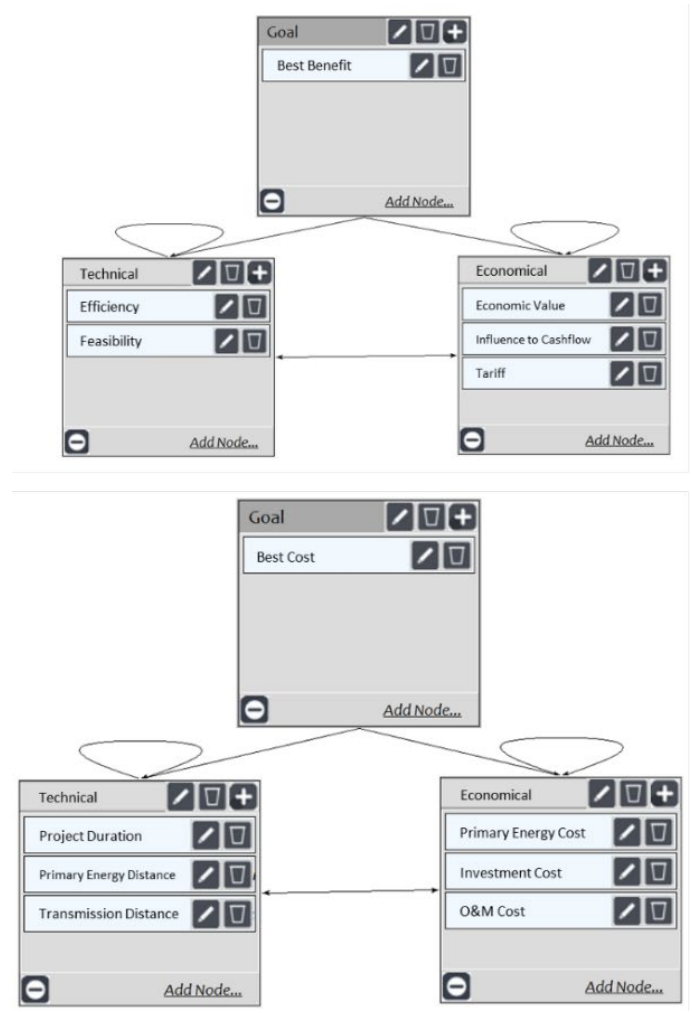

(c) (b)
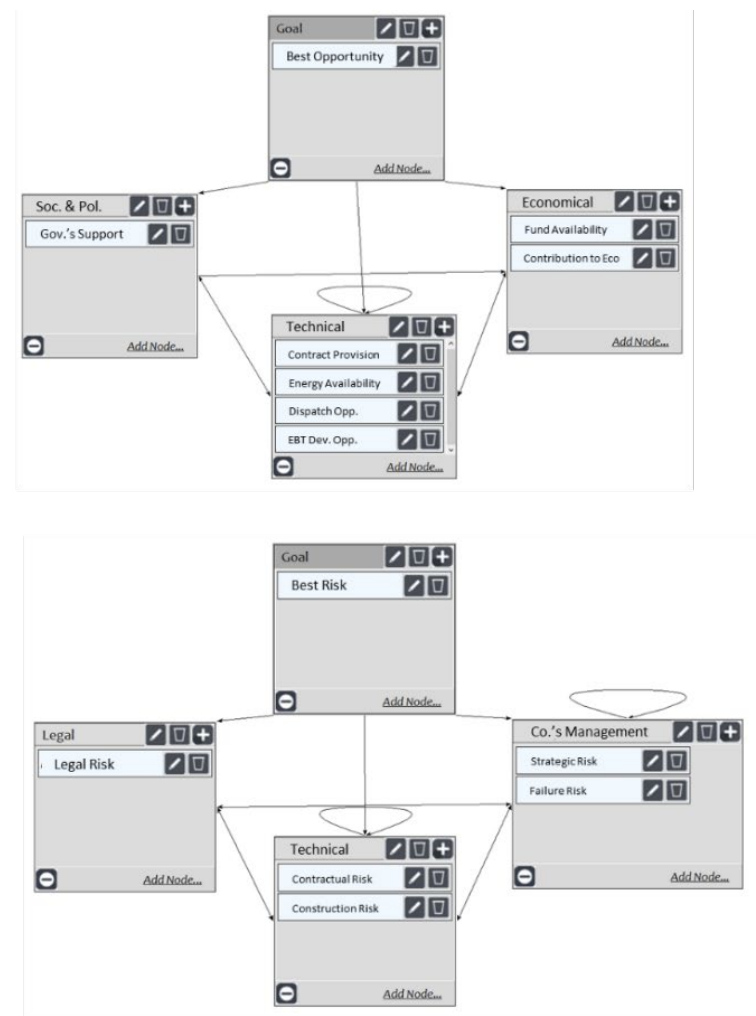

(d)

Figure 2. BOCR Network Structures: (a) Benefit, (b) Opportunity, (c) Cost, (d) Risk.

vision. Thus, the strategic criteria for this model are: (1) Solution and Value Added, (2) High quality, competitive, and environmental friendly, and (3) Sustainable.

Step 3. Identify the criteria and sub-criteria for BOCR networks. After reviewing all of the potential sub-criteria for BOCR network, decision makers chose several sub-criteria that they deemed suitable to be used for company's project selections (see Table 3).

Step 4. Identify the weights of strategic criteria and weights of BOCR. Based on hesitant fuzzy method proposed by Acar et al [24], the weight of strategic criteria and BOCR were composed. The first step is to evaluate the importance of each criteria (see Table 4), then find the envelope from the hesitant evaluation (see Table 5) using fuzzy envelope approach [32].

After finding fuzzy envelopes evaluations from all decision makers, the evaluation were all aggregated using geometric means to become aggregate matrices (see Table 6). The fuzzy weights (see Table 7) are then calculated by calculating each row's geometric mean, and then normalizing that values by dividing it with the highest score in the scale table, which is 10 .

To find the weights for BOCR, then fuzzy weights for Strategic Criteria were multiplied with their respective BOCR fuzzy weights, and then summed to find the fuzzy weights (see Table 8). The fuzzy weights then de-fuzzied.

It was found that the most prioritized strategic criteria in the project selection were "Quality, competitive and environmentally friendly" with a weight of $52.270 \%$, while "Sustainable" occupied the second priority with a weight of
$33.833 \%$ and "Solution and Value Added" occupied the third priority with $13.898 \%$ weight. On the other hand, the most prioritized BOCR in the project selection were "Benefits" with a weight of $33.127 \%$, followed by "Opportunities" with a weight of $23.930 \%$, followed by "Risk" with a weight of $22.054 \%$ and a "Cost" with a weight of $20.889 \%$. From the above results, it can be concluded that in choosing the project, PT X prioritizes the positive impacts obtained from the project compared to the negative impacts.

Step 5. Identify the significant dependencies among criteria and sub-criteria in the BOCR networks. Based on fuzzy DEMATEL proposed by Tabatabaee et al [25], the dependencies of criteria and sub-criteria among networks are identified. Then, after the Matrix $\mathrm{T}$ is composed, then the threshold value for matrix $\mathrm{T}$ is calculated for all BOCR networks by averaging all value in the matrix. The value that are higher than the threshold value will then be considered as significant dependencies and will be analyzed further in this paper.

Then, the Dispatcher (D) and Receiver (R) value were calculated for each of the sub-criteria to understand further regarding its dependencies (see Table 9). From those value, some conclusions can be drawn regarding each of subcriterion dependencies.

For Benefit Network, it can be concluded that Feasibility is the causative factor that most influences other factors. Efficiency is also a causative factor, but does not have a significant effect in this aspect. Tariff and Economic Value are the affected factors that have a big influence with the 
factors in this aspect. The Influence to Company's Cashflow is also an impact factor, but it does not have a large influence with other factors.

For Opportunity Network, it can be concluded that the Primary Energy Sources Availability and Opportunities for Dispatch are causal factors, but do not have a large influence on other factors. Opportunities for EBT Development are impacted factors that have a large influence with other factors. Government's Support, Funds Availability, and Contributions to Economy are also affected factors, but do not have a significant influence with other factors.

For Cost Network, it can be concluded that the Distance between Power plants with the Nearest Transmission, Distance of Primary Energy Sources to Users, and Primary Energy Costs are causal factors, but do not have a large influence on other factors. Investment Cost and Project Phase Duration are the affected factors that have a large influence with other factors. O\&M Costs are also an impact factor, but do not have a significant effect with other factors.

For Risk Network, it can be concluded that Contractual Risk, Failure Risk, and Construction Risk are causal factors and have a large influence on other factors. Legal Risk is an impact factor that has a big influence with other factors. Strategic Risk is also an impact factor, but does not have a significant influence with other factors.

The dependencies between each of the sub-criteria can be described using Influential Relation Map (see Figure 1). Note that only the significant dependencies were drawn in the map. Step 6. Identify the weights of BOCR criteria and subcriteria. The maps developed from DEMATEL analysis will be the base of the network structure for BOCR (see Figure 2). The beginning for BOCR criteria and sub-criteria weights calculation follows the same steps as strategic criteria and BOCR weight according to the network structure. The weights composed from these steps then were used to composed weighted supermatrix (see Table 10). The weights for each sub-criteria (see Table 12) were then identified from the limiting supermatrix.

It can be concluded that for the decision makers, in the Benefit Network, the most important sub-criteria is Tariff, while the least important is Efficiency. In the Opportunity Network, the most important sub-criteria is Opportunity for EBT Development, while the least important is Contract Provision. In the Cost Network, the most important subcriteria is Investment Cost, while the least important is Distance between Power Plant and Transmission. In the Risk Network, the most important sub-criteria is Legal Risk, while the least important one is Contractual Risk.

Step 7. Evaluate and select power plant projects using additive-BOCR and multiplicative-BOCR. The BOCR values for each project were then composed by multiplying the score assigned by decision makers with the weights calculated from the previous steps. Then, the value were normalized for each BOCR networks. Then, additive-BOCR and multiplicative-BOCR were calculated (see Table 13).

It can be concluded that for the decision makers, in the Benefit Network, the most important sub-criteria is Tariff, while the least important is Efficiency. In the Opportunity Network, the most important sub-criteria is Opportunity for EBT Development, while the least important is Contract
Provision. In the Cost Network, the most important subcriteria is Investment Cost, while the least important is Distance between Power Plant and Transmission. In the Risk Network, the most important sub-criteria is Legal Risk, while the least important one is Contractual Risk.

Step 7. Evaluate and select power plant projects using additive-BOCR and multiplicative-BOCR. The BOCR values for each project were then composed by multiplying the score assigned by decision makers with the weights calculated from the previous steps. Then, the value were normalized for each BOCR networks. Then, additive-BOCR and multiplicativeBOCR were calculated (see Table 13).

Based on the additive value, it can be seen that Project C $(0.039)$ has the highest value and the first priority to be implemented by PT X, followed by Project B (0.032), Project A (0.026), Project D (0.023), and finally Project E (0.021)). Project $\mathrm{C}$ gets the highest score because this project has the highest value in the aspect that has the highest weight, namely Benefits and Opportunities, even though this project has a high cost due to low priority weighting on that aspect. In contrast to the project, Project D and Project E which have the lowest value in the aspects of Benefits and Opportunities, even though costs and risks are also low, ultimately get low priority as well.

Based on the multiplicative value, it can be seen that Project $\mathrm{C}(1,175)$ has the highest value and the first priority to be implemented by PT X, followed by Project B $(1,044)$, Project A (0.956), Project D (0.911), and finally Project E (0.905). It can be seen that Project C and Project B scored above 1, which states that the positive impact of the project is greater than the negative impact, while Project A, Project E, and Project D score below 1, which indicates otherwise.

However, this does not mean that Project A, Project E, and Project D are not suitable to be implemented by PT X. In contrast to the additive approach, the multiplicative approach does not pay attention to the weight of the priority of PT X in its calculations. This approach only looks at the ratio between positive and negative impacts generated by the project. That is why this formula does not reflect the company's attitude in choosing projects, where PT $\mathrm{X}$ is willing to bear a large negative impact in order to get a positive impact from the project.

Based on the explanation above, only additive values will be used as a reference to determine whether the project is selected or not (see Table 14). The multiplicative value will be an additional note that the project has a significant negative impact, so that the mitigation that needs to be prepared by PT X must also be sufficient in order to carry out the project well.

\section{CONCLUSION}

Based on AHP's hesitant fuzzy analysis for BOCR's control hierarchy and ANP's hesitant fuzzy for the BOCR network, it is found that for BOCR, the first priority is the Benefits, followed by Opportunities, Risks, and Costs. For Benefit Network, the first priority is Tariff, followed by Economic value, Influence to Company's Cashflow, Feasibility, and last Efficiency. For Opportunity Network, 
EBT development opportunities is the first priority, followed by Dispatch Opportunity, Fund Availability, Primary Energy Availability, Government's Support, Contribution to Economy, and Contract Provision. For Cost Network, the first priority is Investment Cost, followed by Primary Energy Cost, Project Phase Duration, Distance between Primary Energy Sources and User, O\&M Cost and then Distance between Power Plant and Transmission. For Risk Network, the first priority is Legal Risk, followed by Contractual Risk, Construction Risk, Strategic Risk, and Failure Risk.

Based on the synthesis of BOCR, the results of the evaluation, selection and prioritization of projects for the needs of PT X's portfolio are Project $\mathrm{C}$ as the first selected project, followed by Project B in the second priority. Project A is in third priority, but with a consideration that the project has a large negative impact and in a great need for mitigation plan, followed by Project D and Project E with the same consideration.

Previously, PT X's project selection method does not consider the ambiguity or uncertainty of project information, as well as the risks of the project. From this paper, it can be seen that the evaluation using the fuzzy hesitant approach provides a greater range of ratings than the usual assessments. This is because decision makers can include element of doubts in their valuations due to the volatile business environment. This proposed method can illustrate the nature of the uncertainty and ambiguity of the information in the project selection. The application of the BOCR approach to the proposed project selection method can also provide a more comprehensive result related to the positive and negative impacts, such as risks, of the project. This will certainly help PT X in selecting their projects more carefully.

\section{REFERENCES}

[1]. Fitra, S., "Presiden Jokowi Resmikan Program Listrik 35.000 Megawatt" katadata. [Online]. Available: https://katadata.co.id/berita/2015/05/04/presiden-jokowi-resmikanprogram-listrik-35000-megawatt. [Accessed: 15 September 2019]

[2]. Project Management Institute, The Standard for Portfolio Management, Project Management Institute, 2006.

[3]. Levine, H., Project Portfolio Management: A Practical Guide to Selecting Projects, Managing Portfolios, and Maximizing Benefits. Jossey-Bass, 2005.

[4]. Rajegopal, S., McGuin, P., \& Waller, J., Project Portfolio Management: Leading the Corporate Vision. Palgrace Macmillan, 2007.

[5]. Archer, N., \& Ghasemzadeh, F., "Project Portfolio Selection and Management" in The Wiley Guide to Managing Projects, J. Pinto, \& P. Morris, John Wiley \& Sons, 2004, pp. 237-254.

[6]. Cooper, R., Edgett, S., \& Kleinschmidt, E., "New Product Portfolio Management: Practices and Performance" in Product Innovation Management, 1999, pp. 333-351.

[7]. Colson, G., Bruyn, C., \& Rodin, E., Models and Methods in Multiple Criteria Decision Making. Pergamon Press, 1989.

[8]. Kahraman, C., Fuzzy Multi-Criteria Decision-Making: Theory and Applications with Recent Developments. Springer, 2008.

[9]. Bellman, R., \& Zadeh, L., "Decision Making in a Fuzzy Enviroment" in Management Sciences, 1970, pp. 141-164.

[10]. Zadeh, L., "Fuzzy sets" in Information and Control, 1965, pp. 338353.

[11]. Zadeh, L., "The Concept of A Linguistic Variable and Its Application to Approximate Reasoning-1" in Information Sciences, 1975, pp. 199249.

[12]. Torra, V., "Hesitant Fuzzy Sets" in International Journal of Intelligent Systems, 2010, pp. 529-539.
[13]. Saaty, T., Theory and Applications of the Analytic Network Process Decision Making With Benefits, Opportunities, Costs, and Risks. RWS Publications, 2004.

[14]. Wang, W.-M., Lee, A., Peng, L.-P., \& Wu, Z.-L., "An integrated decision making model for district revitalization and regeneration" in Decision Support Systems, 2013, pp. 1092-1103.

[15]. Bai, H., \& Zhan, Z., "An IT Project Selection Method Based On Fuzzy Analytic Network Process" in International Conference on System Science, Engineering Design and Manufacturing Informatization, 2011.

[16]. Ciptomulyono, U., "Model Keputusan untuk Pemilihan Proyek Pembangkit Listrik: Integrasi Metode Analytic Hierarchy Process (AHP) dan Zero-One Goal Programming" in The 4th Indonesia Symposium on Analytic Hierarchy Process, 2006, pp. 147-162.

[17]. Colak, M., \& Kaya, I., "Prioritization of renewable energy alternatives by using an integrated fuzzy" in Renewable and Sustainable Energy Reviews, 2017, pp. 840-853.

[18]. Ebrahimnejad, S., Mousavi, S., Tavakkoli-Moghaddam, R., Hashemi, H., \& Vahdani, B., "A novel two-phase group decision making approach for construction project selection in a fuzzy environment" in Applied Mathematical Modelling, 2012, pp. 4197-4217.

[19]. Erdogan, M., \& Kaya, I., "An Integrated Multi-Criteria Decision Making Methodology Based on Type-2 Fuzzy Sets for Selection Among Energy Alternatives in Turkey" in Iranian Journal of Fuzzy Systems, 2015, pp. 1-25.

[20]. Kabak, M., \& Dagdeviren, M. (2014). Prioritization of renewable energy sources for Turkey by using a hybrid MCDM methodology. Energy Conversion and Management, 25-33.

[21]. Saaty, T., \& Vargas, L., Decision Making With The Analytic Network Process: Economic, Political, Scoial and Technological Applications with Benefits, Opportunities, Costs, and Risks. Springer Science+Business Media, 2006

[22]. Saaty, T., The Analytic Hierarchy Process. McGraw-Hill, 1980.

[23]. Ishizaka, A., \& Nemery, P., Multi-Criteria Decision Analysis: Methods and Software. Wiley, 2013.

[24]. Saaty, T., Decision Making with Dependence and Feedback: The Analytic Network Process. RWS Publications, 1996.

[25]. Fontela, E., \& Gabus, A., The DEMATEL Observer. Battelle Geneva Research Center, 1976.

[26]. Zimmermann, H., Fuzzy set theory and its applications. Kluwer Academic Publishers, 1991.

[27]. Atanassov, K. T., "Intuitionistic Fuzzy Sets" in Fuzzy Sets and Systems, 1986, pp. 87-96.

[28]. Azadeh, A., Nazari-Shirkouhi, S., Hatami-Shirkouhi, L., \& Ansarinejad, A., "A unique fuzzy multi-criteria decision making: computer simulation approach for productive operators' assigment in cellular manufacturing system with uncertainty and vagueness" in International Journal Advance, 2011, pp. 329-343.

[29]. Kiani Mavi, R. and Standing, C., "Cause and effect analysis of business intelligence (BI) benefits with fuzzy DEMATEL" in Knowledge Management Research \& Practice, 2018, pp. 1-13.

[30]. Acar, C., Beskese, A., and Temur, G., "Sustainability analysis of different hydrogen production options using hesitant fuzzy AHP" in International Journal of Hydrogen Energy, 2018, pp. 1-18.

[31]. Tabatabaee, S., Mahdiyar, A., Durdyev, S., Mohades, S. R., \& Ismail, S., "An assessment model of benefits, opportunities, costs, and risks of green roof installation: A multi criteria decision making approach" in Journal of Cleaner Production, 2019, pp. 1-11.

[32]. Liu, H., \& Rodriguez, R. (2014). A fuzzy envelope for hesitant fuzzy linguistic term set and its application to multicriteria decision making. Information Sciences, 220-238. 